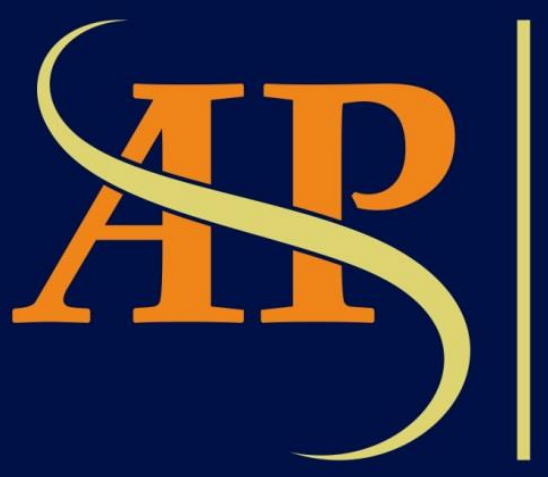

JURNAL ASIA PACIFIC STUDIES

Journal of International Relations Study Program Faculty of Social and Political Sciences Universitas Kristen Indonesia

Volume 2 | Number 2 | July - December 2018 


\title{
THE DECONSTRUCTION AND RECONSTRUCTION OF GLOBAL ENVIRONMENTAL GOVERNANCE: CASE STUDY OF PEAT RESTORATION AGENCY
}

\author{
Verdinand Robertua \\ International Relations, Faculty of Social and Political Sciences, Universitas Kristen Indonesia, Jl. Mayjen \\ Sutoyo 2, Cawang, Jakarta, 13630 \\ verdinand.robertua@uki.ac.id
}

\begin{abstract}
Forest fires in 2015 in Indonesia has destructed severely Indonesian peat and forest. Peat Restoration Agency was established to restore degraded peat and protect the remaining intact peat. The problem is that Indonesia has complex political administration and isolated peatland. Meanwhile there is significant wave of states retreat from global environmental governance. This research would like deconstruct and reconstruct global environmental governance using the case study of Peat Restoration Agency.

This research is a qualitative study with the emphasis of conceptual and theoretical development. Environmental Studies of English School and global environmental governance are the theoretical and conceptual focus respectively. Primary data is collected through semi-structured interview with head of Peat Restoration Agency, environmental activists in WWF Indonesia, WALHI and Greenpeace Indonesia.

There are two key finding in this research. Firstly, the absence of immutability thesis is essential for expanding pluralism in Environmental Studies of English School (ESES). Secondly, deconstruction and reconstruction of global environmental governance has implication toward the deconstruction and reconstruction of environmental diplomacy.
\end{abstract}

Keywords: Peat Restoration Agency, Environmental Studies of English School, environmental diplomacy, Global Environmental Governance, peatland

\begin{abstract}
Abstrak
Kebakaran hutan yang terjadi pada tahun 2015 telah menghancurkan lahan gambut yang sangat luas. Merespons kerusakan tersebut, Badan Restorasi Gambut dibentuk dengan tujuan memulihkan lahan gambut yang rusak dan melindungi lahan gambut yang utuh. Inisiatif ini menghadapi masalah dimana Indonesia memiliki sistem pemerintahan yang kompleks dan lahan gambut yang sulit diakses dari pusat pemerintahan. Tata kelola lingkungan global juga menghadapi masalah dimana negara anggotanya memilih untuk bersikap pasif. Penelitian ini berusaha melakukan dekonstruksi dan rekonstruksi tata kelola lingkungan global melalui studi kasus Badan Restorasi Gambut.

Penelitian ini adalah penelitian kualitatif dengan tujuan penelitian yaitu pengembangan konsep tata kelola lingkungan global dan teori Environmental Studies of English School. Data primer diperoleh melalui serangkaian wawancara dengan kepala Badan Restorasi Gambut, aktivis lingkungan WWF Indonesia, WALHI dan Greenpeace Indonesia

Terdapat dua kesimpulan yang diperoleh penelitian ini. Pertama, penghapusan immutability thesis merupakan bagian dari pengembangan pluralisme dalam Environmental Studies of English School. Kedua, dekonstruksi dan rekonstruksi tata kelola lingkungan global berimplikasi terhadap dekonstruksi dan rekonstruksi diplomasi lingkungan.
\end{abstract}

Kata kunci: Badan Restorasi Gambut, Environmental Studies of English School, diplomasi lingkungan, tata kelola lingkungan global, lahan gambut 


\section{Introduction}

\subsection{Background}

Peatland is a special case in environmental conservation. Peatland is produced by decomposition of woods and other kinds of organic materials (UN Environment 2018). Peatland is able to absorb more carbon and water than ordinary soil but drained peatland is vulnerable for fires. Indonesia is not only rich for its forest biodiversity but also for its peatland material. Indonesia is the fourth largest owner of peatland area after Russia, Canada and Kongo (The Straits Times 2018). 10\% of Indonesian land-based area is peatland which covered around 15 million hectares (Dohong, Aziz and Dargusch 2018).

Peatland ownership brought positive and negative impact. For the local community, peatland helped them to conserve their water, and to develop paludiculture as well as aquaculture such as pineapple, chocolate, coffee and rice (Tata 2018). However, peatland has been degraded massively due to the expansion of residential area, palm oil plantation and wood-based industry (Santosa and Putra 2016). 2015's forest fires has destructed more than 600 hundred thousand hectares of Indonesian peatland (CNN Indonesia 2015). Indonesian giant palm oil industries such as Sinar Mas and Wilmar have been accused as the perpetrators of forest fires in Indonesia (Greenpeace 2008).

According to Kohne (2014), deforestation and land degradation caused land conflict between corporation and local community. Corporation attempted to gain extraordinary benefit from the expansion of palm oil plantation by clearing the land using fires (Bram 2012). However, local communities suffered diseases and water crisis as seen in 2015's forest fires crisis. The victims of peat and forest fires is not only Indonesian citizen but also Singaporean and Malaysian (Varkkey 2011). Peat fires become important agenda in Association for Southeast Asian Nations (ASEAN) and Indonesia is being cornered as the origin of the haze (Heilman 2015). Singaporean and Malaysian questioned Indonesia's environmental responsibility in preventing and mitigating the forest fires and transboundary haze (Forsyth 2014).

In the beginning of 2016, Jokowi established Peat Restoration Agency (BRG) in response to forest and peat fires as well as transboundary haze in Indonesia. The task of BRG is to restore the degraded two million Indonesian peatland in addition with preventing fires in peatland. According to the Presidential Decree 1/2016, BRG is adhoc agency with working period of 2016-2020.

It is important to criticize the effectiveness of BRG. The mandate for BRG is limited with five year term from 2015-2020 and the budget is taken from Ministry of Environment and Forest (Alisjahbana and Busch 2017). According to author, there is contradicting phenomena regarding Indonesia foreign policy on environment and land-use as well as forestry. In one side, Indonesia has signed and ratified many multilateral environmental agreements such as Kyoto Protocol and Paris Agreement. Indonesian constitutional court has also decided to return the forest area to the indigenous communities. According to the 1999 Indonesian Forestry Law, government has the authority to manage and operate the customary forest without any consultation and dialogue with the local forest community. However, constitutional court in 2012 stipulated that customary forest are not belong to state forest and government has to return the customary forest ownership to the indigenous peoples.

There are many problems regarding the implementation of the targets and mandates from those agreements. For example, Indonesia ratified Kyoto Protocol but it failed to effectively develop the government institution capacity in handling the Clean Development 
Mechanism's project (Murdiyarso 2004). Indonesia ratified ASEAN Agreement on Transboundary Haze Pollution in 2014 but there are national law that allowed the method of fire in clearing the land with the maximum of two hectares (UU 32/2009).

This non-linear environmental politics has provoked intensive debate regarding the relevance of International Relations' theoretical development with environmental responsibility specifically English School theory. According to Jackson (2009), English School (ES) is the theory that able to study norms including global environmental governance (GEG). As Molly Cochran (2009) said, ES theory is not normative theory but theory on norms. ES aimed to be able to capture the progress of solidarism as well as the stark reality of the pluralism. In English School theory, global environmental governance has a parallel with the solidarism that emphasized the primacy of non-state actor (Falkner 2012).

According to Bull $(1966,52)$, pluralist stands for "states do not exhibit solidarity of this kind, but are capable of agreeing only for certain minimum purposes which fall short of that of enforcement of the law" meanwhile solidarist stands for "solidarity, or potential solidarity, of the states comprising international society, with respect to the enforcement of the law". Barry Buzan's book "From International Society to World Society" is the first systematic attempt to develop solidarism (Buzan 2004). According to Buzan (2004), English School has solidarism that is very sufficient to understand the problems of GEG. Then the development of solidarism is an important English School research agenda (Schouenborg 2013, Wheeler 2000).

According to Park, Conca and Finger (2008), global environmental governance experienced many conflict between egoistic self-interest of nations and environmental protection. GEG emphasized the transformation from Westphalian system to post-Westphalia system (Paterson 2005). GEG has inspired the creation of hybrid organization such as Forest Stewardship Council, Roundtable Sustainable Palm Oil, Rainforest Alliance (Moog, Spicer and Bohm 2015). GEG is established after Johannesburg Conference 2002 that marked a triumph of non-state actors (Robertua 2016, Backstrand 2006, Yani and Robertua 2018).

This research has an ambition to challenge the hegemony of non-state actors within the GEG. The presence of reform and progress in state's internal and external affairs has opened the debate regarding the effectiveness of the monopoly of non-state actors in GEG (Eckersley 2005). Eckersley (1992) argued that GEG has been a tool for incorporating pillars of ecological democratization such as eco-welfare, resource conservation, animal liberation and preservationism.

\subsection{Research Question}

This research wanted to use the dynamics in GEG to challenge the hegemony of solidarism in English School theoretical development. The clash between environmental activists with government and the debate regarding the primacy of sovereignty are similar to the debate between pluralism and solidarism. English School theory has the potential to offer insights and ideas regarding global environmental governance but it is also important to critically evaluate the presence of solidarism and pluralism.

The establishment of BRG has gained increasing support from environmental activists and represented a challenge toward the occupation of GEG into solidarism concept. This research would like to ask on how to deconstruct and reconstruct the concept of global environmental governance using the case of BRG. 


\subsection{Purpose and objective}

There are three objectives of this research. Firstly, this research aimed to bring recommendation and feedback toward BRG. BRG is still a new organization that have enormous blueprints to be adopted. BRG's daunting task need a critical assessment in a consistent research agenda. Secondly, this research aimed to enrich the contemporary global environmental politics literatures. Scholars has to be more attentive to changes in domestic politics because they have the potential to change the shape and format of GEG.

Thirdly, there is lack of attention among ES scholars regarding environmental issues (Yani and Robertua 2018). Robert Falkner, Sanna Kopra and Andrew Hurrell are noted ES scholars who have produced references and literatures regarding environmental issues. However, GEG literatures in English School is still widely missing.

\section{Literature Review}

\subsection{Environmental Studies of English School (ESES)}

ESES is a research agenda focusing to synergize English School theory with environmental concepts as well as empirical transboundary environmental problems (Yani and Robertua 2018). According to Yani and Robertua (2018), English School theory is blind toward environmental disaster worldwide because English School scholars are not interested to use pluralism and solidarism to understand the need of transformation of current global environmental politics.

In this research, English School theory will be the tool to deconstruct and reconstruct the global environmental governance. English School theory is able to exploit the neglected phenomenon and challenge the dominant assumption in global environmental governance (Bain 2007).

In the case of BRG, we can see that Indonesian government wanted to show their commitment in prioritizing environmental issues. However critics said that government policy and institution is not effective in achieving its core function namely environmental responsibility. For example Indonesia established Indonesian sustainable palm oil (ISPO) in 2011 and used ISPO to compete with Roundtable Sustainable Palm Oil (RSPO) in gaining international status as a responsible actor in environmental politics (Yani and Robertua 2018). For Indonesian government, RSPO has failed to fulfill Indonesian national interest and ISPO is an alternative to better Indonesian position against transnational pressure groups (Adity 2011).

The retreat of state in global environmental governance can be discussed using English School. English School has two basic concepts namely pluralism and solidarism and these concepts will be used as tool to deconstruct and reconstruct global environmental governance using the case study of BRG. According to Liste (2017), norms and value are not taken-for granted. English School aimed to explore to deconstruct the dominant paradigm using pluralism and solidarism (Falkner 2017, Wheeler 2000, William 2015, Cochran 2009, Hurrell 2007).

\subsection{Global Environmental Governance (GEG)}

Why we need to talk about global environmental governance (GEG)? International Relation theorists have to work with ecological thought and global environmental governance 
become a tool to exploit the wealth of ecological thought. As mentioned by Laferrière and Stoett (1999), ecological thought can be used to evaluate International Relations theory. International Relations theories have to consider the growing environmental movement including Eco-socialism and environmentalism. IR theories are limited in exploiting the wealth of ecological thought because the focus is on sovereignty and national interest. We have to expand the unit of analysis into a human being and the neglected part of society by deconstructing and reconstructing GEG.

BRG is one as a solution for Jokowi's regime in implementing Indonesia's commitment in reducing greenhouse gas emission. Alisjahbana and Busch (2017) have highlighted on how there are many weakness in the institutionalization of BRG. According to Alisjahbana and Busch (2017), BRG has insufficient human resources, inadequate funding and inconsistent peatland regulation. As a new organization, BRG need strong political mandate in order to deal with the complexity of regulation and political administration regarding peatland governance.

According to Najam, Papa and Taiyab (2006), the strict notion of sovereignty has hindered an effective implementation of GEG which cause six problems of GEG. They are fragmentation of GEG, lack of cooperation and coordination among international organizations, lack of implementation, compliance, enforcement and effectiveness, inefficient use of resources, GEG outside environmental arena, and non-state actors in a state-centric system. This research will only highlighted the first three factors. Firstly, there are many multilateral environmental agreement that were separated and uncoordinated. There are many overlapping authority and mandate between those multilateral environmental agreements that cause ineffective in pursuing the grand strategy of emission reduction.

Secondly, there is lack of coordination among international organization. World Trade Organization and United Nation Environmental Programme are United Nations family organization but both of them have different notions regarding environmental protection. It is also worsened when global environmental organization have different air quality standards with regional organizations. Thirdly, the failure of GEG is due to lack of implementation, compliance, enforcement and effectiveness. This is the problem with state-centric GEG that emphasized the primacy of sovereignty. Many multilateral environmental agreement are voluntary and non-binding that tolerate the incompliance of member states. It gives the possibility of being free-rider.

\section{Research Method}

\subsection{Research Design}

This is a case study research. From the establishment of BRG, we can see the dynamics of GEG in English School theory. BRG has many context and issues which are relevant to the discussion regarding GEG. For example, BRG faced resistance from palm oil company in implementing the protection of forest. This conflict is a case to show the rivalry between pluralism and solidarism.

This is a qualitative research with interpretivist methodology. According to Porta and Keating (2008), interpretivist methodology allows researcher's opinion inserted into the research due to assumption that there is no universal truth. Interpretivist methodology is related to the epistemology of critical theory that advised for looking injustice and hidden truth in the society. Last but not the least, the ontology of English School is norms and values that are fundamental and constitutive in International Relations. 
When we are talking about research method then we need to know the purpose of the research. The purpose of this research is to identify the process of changing the norms from pluralism to solidarism or vice versa. Both pluralism and solidarism have equal weight that the purpose of the research is to know the evolution from pluralism to solidarism or vice versa. There is no hierarchy between pluralism and solidarism. Therefore English school is a theory to study the dynamics of norms. In this case we are learning the dynamics of global environmental governance as norms that has changing definition and characters from time to time.

\subsection{Research method}

To answer the research question, the author conducted interview with informants from BRG, policy-makers and academician. The author has the opportunity to have semi-structured interview with Nazir Foead (Badan Restorasi Gambut), Leonard Simajuntak (Greenpeace Indonesia), Wahyu Perdana (WALHI) and Zulfira Warta (WWF Indonesia). The author also used books and journals to supplement information and technical details. The method is interpretivist that author can write his personal opinion based on the data and existing literature regarding English School theory.

The focus of this research is to deconstruct and reconstruct GEG as a concept. Why it is important to deconstruct and reconstruct a concept? Concept plays fundamental role in shaping the behaviour and perception of peoples toward certain phenomena. As a concept, GEG will determine government priorities and policies in relation to the problems they deal with. Dingwerth and Pattberg summarized it briefly:

By relating certain phenomena to each other and keeping others apart, concepts fulfill the central function of ordering and structuring our perception of the world. As a result, concepts help us, among other things, to make judgments about the relevance and significance of information, to analyze specific situations, or to create new ideas. Because they allow us to make generalizations, concepts are fundamental to individual as well as collective learning processes (Dingwerth and Pattberg, Global Governance as a Perspective in World Politics 2006, 186).

The problem is that GEG has many interpretations that are different and sometimes contradicting. It is very important to criticize the dominant interpretations of GEG by comparing different definition and utility of GEG. The purpose of reconstruction is to better the ability of policy makers to deal with their problem. As stated in the background, there are many persistent environmental problems in which GEG has failed to response. Transboundary environmental problem is an indication for International Relations scholars to reformulate GEG in order to better equip the policymakers in delivering effective response toward environmental problems.

\section{Results and Discussions}

\subsection{New Peatland Governance in Indonesia}

The problem of peatland governance is related to Indonesian forest and land-use management. Jokowi's administration has significant difference in managing forest in comparison with Suharto's and Susilo Bambang Yudhoyono's era. The first difference is the 
integration between Ministry of Environment and Ministry of Forest. Under Jokowi's leadership, Ministry of Environment and Ministry of Forest is headed by a minister with the new name of Ministry of Environment and Forest. In SBY, Megawati, Habibie and Suharto administration, they are separated.

It is interesting to discuss the impact of the integration between Ministry of Forest and Ministry of Environment. It is commonly accepted that Ministry of Forest has contradictory position with Ministry of Environment. However, Jokowi looked at the role of forest and environment in keeping Jokowi's promises to deliver the policy of social forestry. Two values need to work hand in hand: forest should be protected according to environmental values and forest should be maximized for people's welfare (Wibisono 2015).

The second difference is the integration of Executive Agency (Badan Pelaksana) REDD+ with the Ministry of Environment and Forest and the dismissal of Climate Change National Agency (Dewan Nasional Perubahan Iklim). Under SBY's leadership, BP REDD+ is separated and directly supervised by the president. It is obvious that SBY wanted to empower Indonesia climate diplomacy by appointing skilled and experienced diplomats and practitioners in BP REDD+ and Climate Change National Agency (DNPI) including Rachmat Witoelar.

BP REDD+ and DNPI are part of SBY's environmental diplomacy that emphasized global coalition on environmental issues. Bali Roadmap (UNFCCC COP 13) and NorwegianIndonesian REDD+ agreement are some of notable achievement of SBY's environmental diplomacy. BP REDD+ and DNPI become facilitator between different ministry in implementing Indonesian environmental diplomacy including regional and local government. However, international community was surprised on Jokowi's policy on integration of BP REDD+ and dismissal of DNPI due to their notable performance (Mongabay 2015). There are big questions regarding the capacity and capability of Indonesia climate diplomacy in the UNFCCC after the dismissal of DNPI and the integration of BP REDD+.

The third difference is the establishment of a new agency namely Peat Restoration Agency (BRG). There is a big question regarding overlapping responsibilities and mandate between Ministry of Environment and Forest (KLHK) with BRG. KLHK also has special unit that has responsibilities and mandate to conserve and restore peatland. BRG has a mandate to restore two million hectares degraded peatland in five years. Meanwhile peatland unit in KLHK doesn't have specific target. This capacity and capability gap can result to conflict between both institutions.

\subsection{The Crisis of Global Environmental Governance}

Global environmental governance is derived from global governance. The emergence of global governance is a response toward the failure of states in preventing and mitigating global problems including environmental problems (Dingwerth and Pattberg 2006). Stockholm Summit in 1972 didn't produce tangible and binding resolution on environmental issues and Rio Summit in 1992 didn't involve corporation in preventing and solving global problems (Yani and Robertua 2018). Dissatisfaction toward state-led global governance led to the creation of new global order with heavy involvement of civil society. Johannesburg Conference in 2002 become political foundation of a new global environmental governance.

According to Klaus Dingwerth (2007), there are three types of global governance; international governance, transgovernmental governance and transnational governance. International governance emphasized the superiority of state-centric framework meanwhile transnational governance provided platform for civil society to influence international order. 
Transgovernmental governance is a hybrid form that sub-national actors and subgovernmental bodies can work beyond borders to address global problems. Multi-stakeholder initiative is an example of transnational governance. This research learned from Dingwerth's global governance by advising three types of global environmental governance namely international environmental governance, transgovernmental environmental governance and transnational environmental governance.

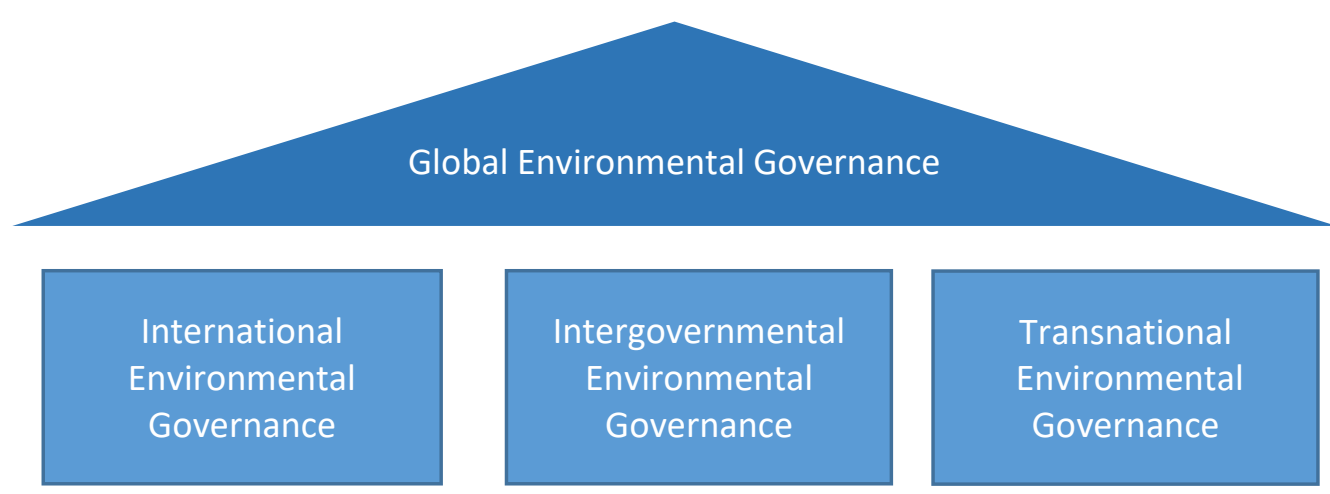

Figure 1. Global Environmental Governance

State-led global environmental governance referred to international environmental governance. There will be a shift from international environmental governance to transnational environmental governance if states failed to keep their promises to implement global environmental agreements. Paterson (2005) also wrote about the emergence of transnational environmental governance in challenging the state hegemony. He mentioned that GEG can be seen as a tool for deterritorialization and multilevel governance.

The notion of deterritorialization and multilevel governance marked the problem of globalization. Globalization has spurred global economic growth by opening trade barrier, the advance of internet communication and new transportation technology. However, globalization has widened the gap between the rich and the poor as well as the green and the brown (Newell 2012). According to Newell (2012), state is a tool for the rich and the brown to preserve the existing injustice and environmental degradation. In order to reform the state, GEG need to be reterritorialized into a new political structure.

Not only global environmental governance, regional environmental organization also faced a crisis similar to state-led international order (Elliot 2011). Association of Southeast Asian Nations (ASEAN) was in limbo due to the irrelevance of ASEAN in dealing with forest fires in Indonesia in 1997 and 2015 (Tan 2005, Kogoya 2014). ASEAN Way was accused as the barrier for effective implementation of multilateral environmental agreement (Nurhidayah, Lipman and Alam 2014). ASEAN Way emphasized diplomacy, non-intervention and consensus decision-making process (Acharya 1997). Environmental activists accused ASEAN Way is a political foundation for states to shield their exploitative practices from international community (Varkkey 2009).

\subsection{The End of Immutability Thesis}

The crisis of global environmental governance to bring significant betterment in environmental issues is used by solidarist to convince that pluralism is failed. Buzan (2004) attempted to convince English School scholar that solidarism has better capacity and 
relevance in explaining changes and progress in global environmental governance. Meanwhile pluralists attempted to bring arguments and proposition that pluralism has ethical desirability in normative and critical issues (William 2015).

In English School theoretical discourse, pluralism and solidarism are competing for bringing their own norms and concepts within the theoretical development of English School (Wienert 2011). Pluralism preferred to emphasize the importance of sovereignty, balance of power, international organization and great power (Bull 1977). In opposite, solidarism brings civil society, global environmental governance and conservationism into spotlight (Buzan 2014). The irrelevance of states in solving environmental issues is a call for greater emphasis on solidarism.

Hedley Bull and Barry Buzan are two prominent English School scholars that have different vision on English School expansion. Bull wanted to maintain the domination of pluralism in explaining progress and dynamics of international order meanwhile Buzan expanded the notion of solidarism by using contemporary projects and cases. Despite championing pluralism as a way of theoretical development, Bull acknowledged the problem of pluralism within environmental studies:

The actual context in which these threats arise, however, is one in which the population policies pursued by states are different and conflicting; there are sharply divergent attitudes towards the goal of economic growth; food, energy and other raw materials are used as weapons in international conflict; some countries pollute the air and water used by others; and a traditional convention that the high seas and its resources are held in common is being eroded. In this context, it is by no means clear that transcending the states system is necessary or sufficient for effective action to deal with these interconnected threats to the environment (Bull 1977, 283).

As stated by Bull in the above quote, states have different perspective in looking the importance of environment and social justice. Developing states put economic development in the top of their foreign policy meanwhile civil society are eager to rejuvenate the role of social justice and environment. Westphalian system is the dominant system in the International Relations so that the opportunities for alternative voice is closed. This is the factor of the rise of pillars of solidarism such as ecological democratization, deliberative democracy, environmentalism, eco-welfare, resource conservation, animal liberation and preservationism. Knowing this critic, Buzan attempted to further develop solidarism as a dominant perspective in Environmental Studies of English School.

This research showed that moving to solidarism is not necessarily the only way to develop environmental studies of English School. Pluralism has its ethical legitimacy in pursuing the relevance of states in solving environmental issues in local, national, regional and global level. Labelling pluralism as irrelevance is equal to biased judgement toward the state-led improvement and the betterment. The key to look on the dynamics of pluralism is the evolving rationality of states in putting policy agenda.

Pluralist maintained that the nature of International Relations will not be changed. States will always struggles for power and the state of nature of International Relations is anarchy (Laferrière and Stoett 1999). Laferrière and Stoett (1999) called this assumption as immutability thesis. However, the author argued that immutability thesis is challenged due to the reality that states do have their uniqueness within their identities including environmental norms. States is mutable which means states can change their directions and priority in their foreign policy and national policy. 


\subsection{Reconstruction of Global Environmental Governance}

Bringing pluralist back into English School research agenda means the reformulation of global environmental governance. Najam, Papa and Taiyab (2006) has elaborated six problems of GEG but the author emphasized three of them namely lack of coordination, lack of compliance and conflict between state and non-state actors. Reconstructing GEG need to convince that there is a solid shift from lack of coordination, lack of compliance and conflict between state and non-state actors into a new kind of coordination, compliance and synergy between state and non-state actors.

Firstly, reconstruction of GEG needs a solid coordination between developed countries and developing countries in achieving global environmental goals. Based on the case study of BRG, coordination between countries will be effective if government put environmental diplomacy as an important foreign policy agenda. Environmental diplomacy was disintegrated from environmental studies due to the domination of economic and business interest within the foreign policy (Qodriyatun 2016).

As stated by Ali and Vladich (2016), environmental diplomacy consists of three components; environmental protection, economic development and social justice. Each of them will correlate and produce conflictual relations. There will be value conflict in regards to the relationship between environmental protection and economic development. Identity conflict is a result of the interaction between social justice and economic development. Lastly, the conflict between social justice and economic development will lead to distribution conflict.

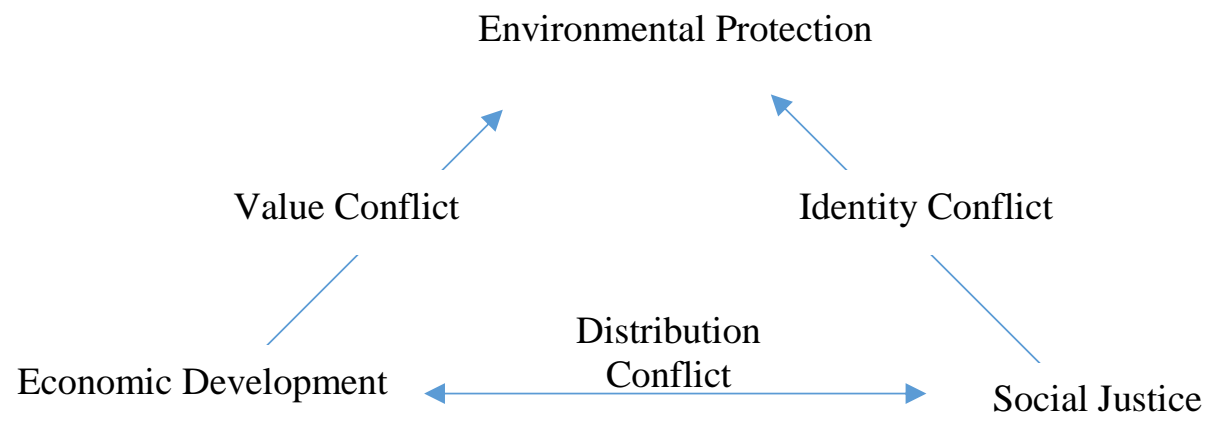

Figure 2. Environmental Diplomacy

(Ali and Vladich 2016)

Ali and Vladich's environmental diplomacy is an attempt to broaden environmental diplomacy encompassing political, social and business dynamic. GEG can use Ali and Vladich's environmental diplomacy to show the domination of economic development within environmental diplomacy. It is not surprising that GEG is being in limbo after environmental diplomacy is used by diplomats to safeguard economic interest. Therefore, this research challenge the domination of business and economic development within environmental diplomacy.

According to author interview with BRG, environmental diplomacy is now not only about economic development but also social justice and environmental protection. To achieve 
an effective environmental diplomacy, BRG worked closely with Ministry of Environment and Forest and Ministry of Foreign Affairs. In the case of palm oil ban in the European Union for example, BRG was involved in bilateral negotiation between Indonesian negotiations with European counterpart. BRG convinced European communities that Indonesian government has done significant reform in the land-use policies especially in the peat sector. In the same time, BRG recommended for Indonesian palm oil plantation to improve its efficiency without massive expansion of plantation area. The problem of coordination in GEG can be tackled with higher degree awareness of the interconnection between economic development, social justice and environmental protection.

Secondly, the role of international law. Lack of compliance toward multilateral environmental agreement is a chronic problem in many regions. For example, ASEAN Agreement on Transboundary Haze Pollution is a binding agreement preventing forest fires and transboundary haze in Southeast Asia. However, the agreement met criticism from international community due to lack of compliance toward the law. According to author, ASEAN Way that emphasized consensus and informal communication was prioritized instead of the enforcement of multilateral environmental agreement.

Again the problem of compliance in GEG need to be dealt with the reconstruction of environmental diplomacy. It is assumed that the presence of punishment and supra-national body are the key factor of the effectiveness of multilateral environmental agreement. This research argued that punishment and supra-national bodies are not the only way to improve the quality of GEG. Dialogue and debate can be effective way for ensuring the effectiveness of GEG. In the context of global environmental negotiation, developed countries are still insist equal participation in emission reduction meanwhile developing countries believed that developed countries should have bigger burden.

The problem of compliance in GEG is closely connected with identities conflict. Developing countries emphasized social justice that developed countries are already rich and prosperous. Developing countries are just starting their industrialization and they wanted to have bigger quota for emissions. The rate of compliance in GEG will be higher if the tools to be used is incentives and facilities. Using punishment will not be effective because there is higher moral obligation for developing states namely the provision of food, education and health services. In the case of BRG, there is bigger attention toward South-South cooperation that BRG will assist Kongo to protect their peatland (Kementerian Lingkungan Hidup dan Kehutanan 2018). In Global Peatland Initiative, BRG and Indonesian government are praised for its commitment toward peatland protection and is committed to help other countries including Kongo. Identities conflict will be solved if the countries emphasized the rights and the obligation of every government.

Thirdly, synergy between civil society and state. Najam, Papa and Taiyab (2006) mentioned that the problem with GEG is that GEG is not able to accommodate global civil society. There is a classical problem in International Relations that emphasized the primacy of states. The existence of civil society challenge the domination of states by using people movement and international communities in order to establish an equal-level-playing field between states and civil society (Dingwerth and Pattberg 2006). Civil society would challenge a one-size-fits-all approach traditionally used by states in solving global problems. The interlinkage between local, national and global level should be understood with the diversity of options and alternatives in the global level.

In the case of BRG, the conflict interaction between states and civil society is disappeared due to the presence of civil society within the BRG. Nazir Foead is an environmental activist that campaign for conservation of endangered species and national 
park. He was working in conservation of Ujung Kulon National Park in West Java and Kayan Menterang in Central Kalimantan. Not only Nazir Foead, BRG also has Aloe Dohong that actively researching Indonesian peatland. He is graduated from doctoral education in Queensland University focusing peatland protection. Dohong was known for his publication on techniques and methods in conserving peatland.

It is also interesting to discuss the new kind of cooperation between state and non-state actor in GEG using the case of BRG. Conflict between state and non-state actor is disappeared not only because BRG consists of noted environmental activists and experts but also the operational framework is using transnational advocacy network. Transnational advocacy network emphasized the confrontational approach using global network in influencing state and corporation behaviour. In the case of BRG, it is noted when BRG head Nazir Foead did impromptu visit to Padang Island in Riau Province in 2016 (Badan Restorasi Gambut 2016). It was recorded and published in Youtube and it gathered nation-wide attention both from public and private enterprises.

In the visit, Foead claimed that there is illegal clearing by paper and pulp company Riau Andalan Pulp and Paper (RAPP) in Padang Island. However, there are some security guard attempting to block the visit by force. The visit is followed-up with meeting in Jakarta mediated by Ministry of Environment and Forestry. Despite of absence of significant policy change, the impromptu visit marked the hybrid nature of BRG combining state with activist network.

The reconstruction of GEG using the case study of BRG resulted to the emphasis of three principles; principles of global commons, common but differentiated responses, and justice and equity. The author learned these principles from Pisupati's paper on environmental diplomacy (Pisupati 2015). Firstly, principles of global commons emphasized the equal participation between states and non-states. This is a confirmation between the synergy between state and non-state actors as shown in BRG's leadership encompassing both civil society and bureaucrat.

Secondly, the implementation of international environmental law emphasized the principle of common but differentiated response. Even though developing countries have privileges in resource exploitation, developing countries also have obligation in implementing sustainable development framework. BRG and KLHK have committed to help Kongo in implementing peat protection and restoration as part of Indonesia responsibility in implementing common but differentiated policy. Indonesia is also involved in Global Peatland Initiative.

Thirdly, the establishment of BRG emphasized the principle of justice and equity. BRG aimed not only restore two million hectares of Indonesian peatland but also part of government campaign in raising awareness regarding environmental protection and social justice. Justice and equity are now mainstreamed into Indonesian business climate including in the palm oil sector. The rise of environmental diplomacy in Indonesian foreign policy means the stronger emphasis of principle of justice and equity.

\section{Conclusions and Recommendations}

This research started with the hypothesis that global environmental governance (GEG) has been failed in preventing global environmental crisis. The recurrence of forest fires, the melting of North Pole and South Pole, global climate deadlock, water crisis and land conflict have sparked new movement in establishing new international order. This research attempted 
to evaluate the performance of GEG by taking the case study of Peat Restoration Agency (BRG) in Indonesia.

Indonesia is now one of twenty largest economy in the world and the largest economy in Southeast Asia. Massive economic modernization has resulted to the rising of millions of new middle class with better access to education and health services. However, Indonesia also faced urgent problems related to environment, land-use and forestry sectors. Forest fires in 2015 is the culmination of the failure of governments in managing its environmental livelihood. The cost of forest fires amounted to hundreds of trillion of Rupiah and impacted to Singapore, Malaysia and part of the Philippines and Thailand. Not only forest fires, Indonesia also faces water shortage in Nusa Tenggara, starvation in Papua, land conflict in Sumatra and Kalimantan and landslides due to deforestation.

Peat Restoration Agency (BRG) is seen as a tool for Indonesian government to restore environmental degradation and prevent further environmental disaster. President Joko Widodo (Jokowi) established BRG in the beginning of 2016 with the purpose to restore two million degraded peatland in Indonesia. Indonesia is the largest tropical peatland country followed by Kongo and Peru. The protection of peatland is crucial due to the ability of peat to absorb carbon and water. Peat can have twice bigger carbon storage than forest. However, the massive expansion of palm oil industry poised farmers to use peatland as palm oil plantation. In order to be able for palm oil plantation, peatland need to be dried through the construction of canal. Dried peatland are vulnerable for fires. In 2015, peat fires is a major factor of the escalation of the duration of forest fires.

There are three two finding in this research. Firstly, the absence of immutability thesis is essential for expanding pluralism in Environmental Studies of English School (ESES). This research focused to understand the marginalization of pluralism and recommend ways to expand it in Environmental Studies of English School (ESES). Global environmental crisis provoked ESES scholars to move from pluralism to solidarism in order to give greater access to civil society to shape and formulate global environmental politics. Marginalization of pluralism is inevitable due to constantly increasing legitimacy for civil society in GEG.

This research argued that pluralism has reformed its main assumption namely immutability thesis. Immutability thesis mentioned that state of nature of International will always be anarchy. The advance of media communication, leadership and domestic politics dynamics are main factors challenging the immutability thesis. BRG is a case showing to ESES scholars that immutability thesis can be abandoned in order to develop pluralism. By taking out immutability thesis, moving to solidarism in expanding ESES is not necessary.

Secondly, deconstruction and reconstruction of global environmental governance has implication toward the reconstruction of environmental diplomacy. The failure of GEG in delivering promises and betterment in global environmental politics was caused by the domination of economic development in the environmental diplomacy. Environmental diplomacy was used only to achieve business and financial development. By deconstructing GEG, this research argued that mainstreaming environmental protection and social justice within environmental diplomacy is needed to enable environmental diplomacy as priority agenda in one's government foreign policy. 


\section{REFERENCES}

\section{Books}

Adity, Keisya Gandestia. 2011. Transnasionalisme Kelapa Sawit: Studi Pengaruh RSPO terhadap Kebijakan Pemerintah Indonesia di Sektor Perkebunan Kelapa Sawit. Yogyakarta: UMY Press.

Bull, Hedley. 1977. The Anarchical Society: A Study of Order in World Politics. Basingstoke: Palgrave.

Buzan, Barry. 2014. An Introduction to the English School of International Relations: The Societal Approach. Cambridge: Polity Press.

-. 2004. From International to World Society: English School Theory and the Social Structure of Globalisation. Cambridge: Cambridge University Press.

Dingwerth, Klaus. 2007. The New Transnationalism: Transnational Governance and Democratic Legitimacy. Basingstoke: Palgrave MacMillan.

Eckersley, Robin. 1992. Environmentalism and Political Theory: Toward An Ecocentric Approach. London: UCL Press.

Greenpeace. 2008. Burning up Borneo. Amsterdam: Greenpeace.

Hurrell, Andrew. 2007. On Global Order: Power, Values and the Constitution of International Society. Oxford: Oxford University Press.

Kogoya, Lidea Fera. 2014. Kegagalan AATHP ASEAN Dalam Menanggulangi Masalah Kebakaran Hutan dan Pencemaran Asap di Indonesia: Tahun 2003 (Thesis). Yogyakarta: Universitas Gadjah Mada.

Laferrière, Eric, dan Peter Stoett. 1999. International Relations Theory and Ecological Thought: Towards Synthesis. London: Routledge.

Najam, Adil, Mihaela Papa, and Nadaa Taiyab. 2006. Global Environmental Governance: A Reform Agenda. Manitoba: International Institute for Sustainable Development.

Newell, Peter. 2012. Globalization and the Environment: Capitalism, Ecology and Power. Cambridge: Polity Press.

Pisupati, Balakrishna. 2015. South-South Cooperation and Environmental Diplomacy Options for India. Chennai: Forum for Law, Environment, Development and Governance (FLEDGE).

Schouenborg, Laust. 2013. The Scandinavian International Society: Primary Institutions and Binding Forces 1815-2010. Oxon: Routledge.

Wheeler, Nicholas. 2000. Saving Strangers: Humanitarian Intervention in International Society. Oxford: Oxford University Press.

William, John. 2015. Ethics, Diversity and World Politics. Oxford: Oxford University Press. 


\section{Chapter in Book}

Ali, Saleem, and Helena Vladich. 2016. "Environmental Diplomacy." In The SAGE Handbook of Diplomacy, by Costas Constantinou, Pauline Kerr dan Paul Sharp, 601-616. London: SAGE.

Bull, Hedley. 1966. "Grotian Conception on International Society." In Diplomatic Investigation: Essays in the Theory of International Politics, by Herbert Butterfield dan Martin Wight, 5173. Michigan: Allen \& Unwin.

Eckersley, Robin. 2005. "Greening the Nation-State: From Exclusive to Inclusive Sovereignty." In The State and Global Ecological Crisis, by Robin Eckersley dan John Barry, 159-181. Massachusets: MIT Press.

Falkner, Robert. 2017. "The Anarchical Society and Climate Change." In The Anarchical Society at 40. Contemporary Challenges and Prospects, by Hidemi Suganami, Madeline Carr dan Adam Humphreys, 198-215. Oxford: Oxford University Press.

Jackson, Robert. 2009. "International Relations as a Craft Discipline." In Theorising International Society: English School Methods, by Cornelia Navari, 21-39. New York: Palgrave Macmillan.

Park, Jacob, Ken Conca, and Matthias Finger. 2008. "The death of Rio environmentalism.” In The Crisis of Global Environmental Governance, by Jacob Park, Ken Conca dan Matthias Finger, 1-13. Oxon: Routledge.

Paterson, Matthew. 2005. “Global Environmental Governance.” In International Society and Its Critics, by Alex Bellamy, 163-178. Oxford: Oxford University Press.

Porta, Donatella della, and Michael Keating. 2008. "Introduction." In Approaches and Methodologies in Social Sciences: A Pluralist Perspective, by Donatella della Porta dan Michael Keating, 117. Cambridge: Cambridge University Press.

\section{Journals}

Acharya, Amitav. 1997. "Ideas, Identity, and Institution Building: From the 'ASEAN Way' to the 'Asia-Pacific' Way." Pacific Review 319-346.

Alisjahbana, Armida S., and Jonah M. Busch. 2017. "Forestry, Forest Fires, and Climate Change in Indonesia." Bulletin of Indonesian Economic Studies 111-136.

Backstrand, Karin. 2006. "Multi-Stakeholder Partnerships for Sustainable Development: Rethinking Legitimacy, Accountability and Effectiveness.” European Environment 290-306.

Bain, William. 2007. "One order, two laws: recovering the 'normative' in English School theory." Review of International Studies 557 - 575.

Bram, Deni. 2012. "Kejahatan Korporasi dalam Pencemaran Lintas Batas Negara: Studi Pencemaran Kabut Asap Kebakaran Hutan di Indonesia." Law Review 11 (3): 377-393.

Cochran, Molly. 2009. "Charting the Ethics of the English School: What "Good" is There in a Middle-Ground Ethics?” International Studies Quarterly 203-225.

Dingwerth, Klaus, and Philipp Pattberg. 2006. "Global Governance as a Perspective in World Politics.” Global Governance 185-203. 
Dohong, Aloe, Ammar Abdul Aziz, and Paul Dargusch. 2018. "A Review of Techniques for Effective Tropical Peatland Restoration." Wetlands 275-292.

Elliot, Lorraine. 2011. "ASEAN and environmental governance: rethinking networked regionalism in Southeast Asia." Regional Environmental Governance. Geneva: Procedia. 61-64.

Falkner, Robert. 2012. "Global environmentalism and the greening of international society." International Affairs 503-522.

Forsyth, Tim. 2014. "Public concerns on transboundary haze: a comparison of Indonesia, Singapore and Malaysia." Global Environmental Change 25: 76-86.

Heilman, Daniel. 2015. “After Indonesia's Ratification: The ASEAN Agreement on Transboundary Haze Pollution and its Effectiveness as a Regional Environmental Governance Tool." Journal of Current Southeast Asian Affairs 95-121.

Kohne, Michiel. 2014. "Multi-stakeholder Initiative governance as assemblage: Rountable Sustainable Palm Oil as a Political Resource in Land Conflicts related to Oil Palm Plantation." Agriculture Humanity 469-480.

Liste, Philip. 2017. "International Relations Norms Research and the Legacies of Critical Legal Theory." 11th Pan-European Conference on International Relations (EISA). Barcelona: European International Studies Association. 1-22.

Moog, Sandra, Andre Spicer, and Steffen Bohm. 2015. "The Politics of Multi-Stakeholder Initiatives: The Crisis of the Forest Stewardship Council.” Journal of Business Ethics 469-493.

Murdiyarso, Daniel. 2004. "Implication of the Kyoto Protocol: Indonesia's Perspective." International Review for Environmental Studies 145-156.

Nurhidayah, Laely, Zada Lipman, and Shawkat Alam. 2014. "Regional Environmental Governance: An Evaluation of the ASEAN Legal Framework for Addressing Transboundary Haze Pollution ." Australian Journal of Asian Law 1-17.

Robertua, Verdinand. 2016. "Multi-stakeholder Initiative for Sustainable Development: An English School Perspective ." Jurnal Sospol 154-170.

Santosa, Mas Achmad, and Januar Dwi Putra. 2016. "Enhancement of Forest and Peatland Governance in Indonesia." Indonesian Journal of International Law 344-352.

Tan, Bryan. 2005. "The Norms that Weren't ASEAN's Shortcomings in Dealing with Transboundary Air Pollution." International Environmental Politics 1-6.

Varkkey, Helena Muhammad. 2011. "Addressing Transboundary Haze through ASEAN: Singapore's Normative Constraints." Journal of International Studies 83-101.

Varkkey, Helena Muhammad. 2009. “Indonesia Perspectives on Managing the ASEAN Haze.” Jurnal Sarjana 24 (1): 83-101.

Wienert, Matthew S. 2011. "Reframing the Pluralist - Solidarist Debate." Millenium - Journal of International Studies 21-41.

Yani, Yanyan Mochamad, and Verdinand Robertua. 2018. "RSPO, ISPO and Global Environmental Governance: An English School Perspective.” Jurnal Hubungan Internasional Universitas Muhammadiyah Yogyakarta 99-112. 
Yani, Yanyan Mohammad, and Verdinand Robertua. 2018. "Environmental Studies of English School: Case Study of Forest Fires in Indonesia and Transboundary Haze in Southeast Asia." Journal of ASEAN Studies 117-135.

\section{Internet}

Badan Restorasi Gambut. 2016. Sidak Kepala BRG ke Pulau Padang. Accessed May 7, 2018. https://brg.go.id/portfolio-types/sidak-kepala-brg-ke-pulau-padang/.

CNN Indonesia. 2015. BNPB: Kebakaran Hutan 2015 Seluas 32 Wilayah DKI Jakarta. Accessed June 18, 2018. https://www.cnnindonesia.com/nasional/20151030133801-20-88437/bnpbkebakaran-hutan-2015-seluas-32-wilayah-dki-jakarta.

Kementerian Lingkungan Hidup dan Kehutanan. 2018. Indonesia dalam Global Peatland Initiative (GPI). Accessed June 22, 2018. http://ditjenppi.menlhk.go.id/index.php/berita-ppi/2872indonesia-dalam-global-peatland-initiative-gpi.

Mongabay. 2015. BP REDD+ Dibubarkan, Kredibilitas Pemerintah Dipertanyakan. 30 1. Accessed June 24, 2018. http://www.mongabay.co.id/2015/01/30/bp-redd-dibubarkan-kredibilitaspemerintah-dipertanyakan/.

Qodriyatun, Sri Nurhayati. 2016. Terabaikannya Lingkungan Hidup dalam Pembangunan. 1 December. Accessed November 3, 2017. http://berkas.dpr.go.id/puslit/files/info_singkat/Info\%20Singkat-VIII-24-II-P3DI-Desember2016-19.pdf.

Tata, Hesti Lestari. 2018. Paludikultur: Praktik Pengelolaan Lahan Gambut Berkelanjutan. Accessed July 7, 2018. http://pojokiklim.menlhk.go.id/uploads/news/1524105985_Pojok\%20Iklim_18418_paludikult ur-min.pdf.

The Straits Times. 2018. Indonesia praised for efforts on peatlands. Accessed June 6, 2018. https://www.straitstimes.com/asia/se-asia/indonesia-praised-for-efforts-on-peatlands.

UN Environment. 2018. Historic agreement signed to protect the world's largest tropical peatland. Accessed June 6, 2018. https://www.unenvironment.org/news-and-stories/pressrelease/historic-agreement-signed-protect-worlds-largest-tropical-peatland.

\section{Newspaper}

Wibisono, Christianto. 2015. “Kedaulatan Asap RI.” Kompas, 27 October: 7. 